IZABELLA ŁABĘDZKA

Adam Mickiewicz University

\title{
Gao Xingjian's Dialogue with Literary and Visual Traditions
}

Gao Xingjian's narrative prose and dramas are well-known for recurrent motives of wandering, exile, flight, realistic or imaginary travel, especially in Alarm Signal (Juedui xinhao), The Bus-stop (Chezhan), Soul Mountain (Lingshan), Escape (Taowang), and Snow in August (Bayue xue), written in the 1980 s and the 1990s. His characters never feel at home; they keep moving or at least wish to move. Some of them cannot cope with their own, disintegrated identity which prevents them from feeling rooted. Others keep dislocating themselves to remain true to their convictions and values. Their creator's life is also subject to the characteristic rhythm of a journey which is spatial and intellectual at the same time. The historic conditionings of the final decades of the $20^{\text {th }}$ century in Mainland China were the direct reason for which the Chinese writer turned into a homo peregrinus for a certain time and he gave privileged position in his work to characters who embarked on a similar pilgrimage towards freedom and self-cognition; the journey became their modus vivendi. On the other hand, their repetitive efforts of embarking on still more quests and journeys might have been driven by the fear of becoming rooted and consequently fossilized, and not by any external factors.

Born (1940) and raised in South-Eastern China and then educated in the North, Gao Xingjian returned for a while to the South in the first half of the 1980 s, as a mature artist who already had his playwright's début. He made his 
geographical, cultural and spiritual journey across the basin of the Yangtze River (Changjiang) as a political exile from Beijing, during the communist party campaign against the "spiritual pollution" with Western culture. Finally, he emigrated to Germany in 1987 and then journeyed to France where he has been living until now. The eighty-year-old artist is still a wanderer peregrinating all over the world, but now he is doing it as a well-recognised painter, stage director and author who meets his readers and audience.

However, his long journey has always had more dimensions than just the space. In $A u$ plus près du réel, he spun an interesting story about artistic creativity, with a particular focus on writing which he saw as a substitute of geographic travels and also about his desire to be everywhere and to get to know everything; he saw travelling as a means of getting closer to reality and experiencing life to the fullest (Gao, Bourgeois 64). A journey through the physical space may be impossible at times, but it can also be done in the imaginary space, travelling across various arts and cultural traditions. Such a virtual journey during which the traveller may freely choose the route and its level of difficulty takes him through time barriers without any restrictions and allows him to draw freely from the traditional and modern literature and art. Painting, film, dance, theatre and poetry with their complex techniques and narrative strategies, studied separately and jointly and read and interpreted in a novel way may become an inexhaustible source for regenerating the language of art and a method to find new ways of perceiving the world and describing an individual human experience.

Since he embarked on his artistic path, Gao Xingjian has always had an incredible ability to assimilate the languages of various arts and artistic forms representing various epochs and cultures. Gao was simultaneously an avantgarde artist (in the supra-historic sense of the notion) and a traditionalist. His approach to tradition was free from bias and anxiety. In contrast to many other experimenters, he did not treat the past as an expendable burden which should be radically discarded. He preferred to see the tradition in a thoroughly thoughtful, rational manner, with the intention to use it for creating something new and valuable. In Night Talks in Beijing (216), he noted that every creative artist who was searching for his own path had to constantly analyse the tradition, or else he would bend under its burden. True to his word, he was an avid observer of tradition and then he drew extremely inspiring conclusions. He saw a never-ending parade of topics and forms of expressions in old Chinese prose, traditional theatre and drama and the art of story-telling. He was particularly fascinated by non-elite, popular literary and para-literary styles which in ancient China were particularly heterogeneous, capacious and flexible which allowed 
for reciprocal borrowings, intertwining of motives and exchange of story-telling techniques. He discovered creative impulses and sources of inspirations for modern theatrical artists in ancient religious ceremonies of ethnic minorities in South-Western and South-Eastern China, in their theatre and exorcist dance, the art of folk story-telling, street shows of travelling salesmen peddling their wares, performances of village troupes acting on makeshift stages, puppet and mask theatres, circus and acrobatic shows, martial arts and even in monkey trainers' tricks. He was no less interested in concepts drawn from Western culture, literature and arts. Already in his early literary essays from the beginning of the 1980 s collected in Preliminaries to the Technique of Modern Narrative Prose (1982), and also in his theatre essays published under the title In Search of Modern Theatre (1988), one could notice his wide knowledge of trends in modern literature and playwriting of the West. He also employed it in his own plays and literary works, particularly in three plays from the years 1982-1985: Alarm Signal, The Bus-stop and Wild Man as well as in his novel Soul Mountain.

Gao Xingjian's early essays and plays confirm that he was interested in theatrical concepts of various reformers of the $20^{\text {th }}$ century theatre such as Vsevolod Meyerhold (1874-1940), Bertolt Brecht (1898-1956), Antonin Artaud (1896-1948) and Jerzy Grotowski (1933-1999). In order to restore in the theatre its long-lost feature of theatricality, Gao - similarly to Meyerhold - turned to the actor, seen as the axial point of the theatre, and to the theatrical convention. Meyerhold's actors showed the audience acting with distance, were able to improvise and used their creative energy to encourage the audience to actively react to the theatrical work. As a stage director, Meyerhold boldly disposed of the limitations of the box stage, discarded naturalistic decorations and moved the acting space towards the audience. He was striving to remove the limitations of the space and he considered the kinetic structures an effective means for removing the tedious unity of space. He also noticed the growing role of the film art which was slowly turning into the symbol of new imagination in the times of visual change. According to Meyerhold, the aesthetics of the film was not only influencing the acting style, but also the dramatic structure which should become more episodic (Braun 254). In his theatre, the stylisation made all decorations redundant. The physique of the actor was prominent. In his discussion of biomechanics, Meyerhold pointed towards the fact that mental factors were pre-determined by specific physiological processes (Braun 62). The correlation of the psychological and physical factors was ranked important also in Gao Xingjian's definition of acting. Meyerhold rejected the psychologism of Chekhov because he considered the word to be of lesser importance as compared with the movement and action which were the essence of theatre. Meyerhold 
preferred to perceive the theatre as the synthesis of the word, music, graphic elements and the actor who was also a dancer, singer, gymnast, tumbler and clown (Braun 254).

Gao Xingjian was also convinced that the nature of the art of theatre was simultaneously synthetic and autonomous. In The Means of Modern Theatre, he adhered to the opinion of the $20^{\text {th }}$ century theatre reformers that the action is the essence of theatre and the actor is its central point. In Dramaturgical Method and the Neutral Actor written a little later he noted that the spoken drama ( haju) imported from the West at the beginning of the $20^{\text {th }}$ century reinforced the domination of the word on stage which consequently resulted in the atrophy of modern theatre. Seeking an alternative to such a theatrical model, Gao Xingjian turned towards theories of Antonin Artaud; they were often echoed in Gao's theatrical essays. Both artists perceived the dramatic work in terms of its presentation on stage. Neither of them trusted the word as the sole means of theatrical expression and they wished to restore its quality of sound, poetry and magic as well as its sensual value. Artaud (37-41) definitely intended to return to breathing and flexibility as the source of language, ceasing to perceive the word solely in terms of logic, grammar and discourse. He wanted to hear it as a sound in combination with the body action. Gao and Artaud also shared their understanding of the theatrical space, the tasks of the playwright and director and the actor-spectator relationship. Both of them strived to remove the barrier between the stage and the audience and to restore a more direct contact between actors and spectators by surrounding them with a non-linear plot. The focal point in Artaud's plays was the actor, while all the means of artistic expression were perfectly balanced and interrelated in order to create networks of meanings of considerable emotional and intellectual complexity. The rejection of the dictate of the word and the dictate of the author resulted in the new understanding of the theatrical performance, a performance which was emerging/materializing before the audience. Artaud radically negated the Western model of the theatre of the word which was just a branch of literature, ignoring the visual side and displaying clear psychological tendencies. He felt much more akin to the concept of Eastern theatres created by the culture of gestures, with theatrical languages structured similarly to local everyday languages which were ideographic and retained an encoded closeness of the word and thing established in accordance with the laws of symbolism and analogy.

Gao Xingjian's ideal of the theatre described in his essay The Pros and Cons of the Reform of Traditional Chinese Music Drama from the mid 1980s and called by him the Modern Eastern Theatre (dongfang xiandai xiju) displayed many similarities to Artaud's concept. It was to be based on the foundation 
of re-thought traditional Chinese theatre and to stay separate from Western theatre. It was to include singing, recitation, acting and acrobatics, true to the theatrical tradition, while avoiding any non-creative imitation of reality and stylisation. This new Eastern theatre focused on the actor on the empty stage who had to make masterly use of circus art, martial arts and magic, combining his acting skills with the art of storytelling. The main categories of Gao's theatrical aesthetics were acting (dongzuo), process (guocheng), metamorphosis (bianhua) and contrast (duibi).

Gao Xingjian's ultimate goal was the comprehensive synthesis of arts and the balance of media in theatre, but he did not side with Meyerhold and Artaud's dislike of psychological theatre. Meyerhold's suggestion on not juxtaposing the convention and the realistic theatre was approved by the Chinese theatre reformers at the beginning of the 1980s. In his early experimental plays, Gao Xingjian did not negate the realistic convention either, but he appreciated a more subjective approach. He was interested in the presentation of the internal world of a character and in the discussion of current reality from the individual perspective. He was probably very well aware that the Chinese audience was accustomed to a coherent plot and felt comfortable when they knew what the point of the story was, preferring unambiguity of its contents. It was Bertolt Brecht with his discussion of acting in traditional Chinese theatre who not only helped Gao Xingjian to consolidate his own theory of acting with distance but also reminded him of the affiliations between theatre and the art of storytelling. Brecht, who was fascinated by the Far Eastern theatre himself, suggested that an actor could also be a story-teller, that acting could ultimately return to its narrative function and that good actor always kept a double identity: he performed his part and retained his objectivity while telling the story and commenting on it. Gao Xingjian found sources of such double identity also in traditional Chinese oral literature and in the art of itinerary story-tellers who had to spin their tales in an attractive manner, instantly take up the roles and leave them just as fast in order to comment on their story from a distance. He discussed it in his two essays entitled What kind of theatre do we need? and I and Brecht. The tradition of Chinese oral literature, reaching many centuries back, suggested to him the ways to introduce epic elements into his plays and encouraged to try to introduce on stage some techniques typical of the narrative prose.

Initially Gao Xingjian tested new narrative strategies compatible with realism, but in later years he consistently introduced much bolder solutions. His novel concepts reached down to the level of dramatic text organisation. He gave up traditional methods of splitting the play into acts and scenes. Instead, he used episodes which were loosely interconnected or not connected at all. 
Some of his techniques were similar to film cutting, others - to dream poetics. He structured his text with recurring musical motives. Being an avid painter, he developed an ability to use light and stage props in a restrained yet deeply symbolic manner. At the same time, he questioned the stage illusion and the conventional representation strategies. He requested that actors depart from their roles and then adopt them again. He multiplied meta-theatrical and meta-dramatic tricks. He introduced the concept of "theatre within theatre" and emphasised the self-referential character of the dramatic text. He disturbed the passive perception of the text and demanded that his readers/spectators become more active and use their imagination in the process of perceiving his work. He freely roamed across various expanses of art, as a novelist and short story writer, playwright, critic and essayist, painter and an experimenting film director, unreservedly testing various techniques and crossing the borders and limitations of these arts.

Soul Mountain, a novel written in the years 1982-1989, seems to be the essence of his theoretical deliberations of the 1980 os and a virtuoso show of skilfully intertwined elements of literary and aesthetic traditions of China and the West. By juxtaposing various techniques of storytelling derived from high and low literature, meta-literary reflection against a fantasy story in the classical style, internal monologue against dramatised dialogue, dry scientific report, a record of small talk and a mythical story, he was able to prove that there were alternative methods of structuring the plot and ordering the narrative matter, and that none of them could claim to be the sole, dominating one. He constantly questioned the status of the character in the novel, particularly the protagonist. By reducing him to the personal pronoun, Gao proved that the protagonist did not necessarily have to be the axial point of the story or the binding element of the narrative in the traditional sense. Hence, he was pointing out that various styles of the narrative were just options, prevented them from setting into pre-determined shapes, and tirelessly transformed them and suggested still new solutions.

Gao Xingjian derived his techniques of structuring the plot both from careful observation of the reality with its transformations and from his knowledge of modern art acquired in the course of his education as a philologist and as a result of his broad spectrum of artistic interest. His essays on literature and theatre written in the 1980 os prove that even at that time he already preferred non-storyline dramatic and novel forms, he gave equal rights to illogicality and did not trust the simple cause-and-effect logic. Gao Xingjian knew perfectly well that human life was full of mysteries, reticence and understatements and it could not be pushed into transparent, schematic vectors of cause and effect. 
It was obvious for him that life does not consist of simple stories with a clearly marked beginning and end. It is full of incoherent fragments, unfinished or broken storylines or stories which run parallel, unexpectedly cross one another or overlap, and other stories which will never end, or which will always remain hypothetical or just imagined. The world and human life has a kaleidoscopic and ever-changing nature which is difficult to grasp. Therefore, the incessant metamorphoses of the events, people and things demand adequate means of artistic expression. A typical, linear storyline is unable to reflect their complexity and changeability. Also, the omniscient narrator has become a slightly outdated figure in the modern narrative prose. Seeking new solutions and modes of novelistic expression, Gao Xingjian often ventured into the realms of other arts: film, painting and music. He realised that a modern audience lived in a world which had changed dramatically throughout recent decades: theirs was the reality of intense images and multi-sound which disrespected orderly narrative and profuse descriptions. Therefore, modern literature should be able to employ variable rhythms of the story, inter-changeability of images, accelerating and slowing tempi, close-ups and long shots, retrospections and future projections and the stream of consciousness which allowed to analyse the character's psyche. He discussed it in his essay On the Idea of Fiction and Writing Technique. In his opinion, the film art was close to the contemporary world, teaching how to look attentively, watch carefully and perceive comprehensively. Narrative strategies of the film were better suited to the fast tempo of modern life with its rhythm punctuated by constantly changing images which primarily appealed to the eye and enforced the perception from varying perspectives. Gao Xingjian's discoveries harmonised with the words of the authors of French post-war new novel, who approximately two, three decades earlier noted that we did not experience time or space as a continuum, but only fragmentarily (Butor 1964: 95-96). Michel Butor, in his essays on literature, emphasised the speed of the modern world and its transformations, as well as the inadequacy of story-telling techniques which were unable to integrate the multitude of information and new relations. Therefore, one had to seek new solutions for the narrative in novels. French writers, searching for such new models turned towards film, music and painting.

Gao Xingjian considered theatre and literature as multilingual, multi-material arts which could boldly use techniques pertinent to other arts. In his narrative prose, he gladly combined various literary genres and styles. Similarly, he approved of heterogeneous materials of his dramatic pieces. He combined elements of tragedy and comedy, absurd and realism, dialogue and monologue, essay and poetry, common and literary. In doing so, however, he always cared 
for the consistency and order of his theatrical or literary work. He derived such structural, ordering elements not only from verbal arts, but also from visual ones and from music.

In various interviews and theoretical studies, Gao Xingjian discussed his musical taste and listening to music while writing prose and dramatic works. He pondered if it would be possible to make the writing process closer to composing music. Striving to make the language more musical, he emphasized its rhythm and the change of tones in dialogues, monologues and simple narrative. He also discussed these issues in Modern Chinese Language and Literary Composition. The musical quality of the language gave the narrative a poetic value; it was noticeable not only on the aural level of a prosaic or dramatic text. Gao Xingjian tried to give to his prose and plays the structural characteristics typical of music. He used specific music forms, such as the rondeau, or quartet (The Bus-stop; The Week-end Quartet). He used the leitmotif, a technique characteristic for music, not only to put the drama contents in order, but he also ascribed important symbolic meaning to it. He also introduced sound and topical polyphony in his works. The phenomenon of topical polyphony consisted in splitting the story into many plots which were loosely connected or not connected at all. (Wild Man; The Other Shore). The sound polyphony (The Bus-stop) consisted of various configurations of separate voices. Gao achieved the diversity of sound effects by overlapping or intertwining parallel dialogues of a few characters, by separating one or more leading voices against a number of supporting ones, by clashing a dialogue with a monologue and by contrasting human voices with music. Soul Mountain includes some examples of topical and sound polyphony alike. The actual journey in search of the titular mountain was the leading motive and the binding material; it also symbolised the spiritual journey within. This thread was bearing bead-like elements: separate stories, fragments of dialogues, soliloquies, remarks which often grew to a substantial size and became parallel narratives, similar to various melodic lines in music. The linguistic diversity of these fragments was related to a change in the sound layer. Also, the collage-like, non-uniform structure of the text, the presence of stylization techniques, pastiche of various manners of speech, automatic recordings of everyday conversations and meta-literary digressions fostered the development of a new network of inter-textual relations. Such a polyphonic, collage-like text became a riddle which demanded from its reader a solution by finding hidden relations between its fragments.

Such complex narrative strategies seem to suggest an inspiration by Western modernism, avant-garde and post-modernism, but the influence of Chinese classical philosophy would be equally justified, particularly of Taoist one with 
its processual and relational perception of the whole reality: space, nature and man. The Taoists do not see the world as static, but rather as changing, liquid and constantly on the move. The cosmic network of relations is dynamic and the reality is an incessant flow and circulation of energy of fluid, all-permeating character. Such perception of the world in terms of the process, relation and dynamics is holistic; it removes all dualistic divisions and liberates one from the bonds of one-sided perception. Gao Xingjian's affinity with polyphony, collage, film montage and his approval of the stream of consciousness and the stream of the language allows to assume that all our surroundings combine with all the things generated by our mind to create a network of mutual relations, to a greater extent that it would seem at the first glance. In his essay On the Idea of Fiction and Writing Technique, Gao Xingjian considered the stream of consciousness to be a special kind of artistic, narrative language which disregarded the sequence of time and was able to join such distant domains as the remembrance and reality, the past and the present; it could also break the limitations of space and juxtapose the illusion, dream and reality. Everything was joining the uniform stream of things real and imagined, material and elusive.

Such a holistic, synthetic vision is present in all the works by Gao Xingjian. Although he knew perfectly well that language was the main tool of his work, he was also aware of its limitations. He saw it as a blessing and a curse, as a cramped prison and an effective tool for self-expression. He often discussed writing in terms of music, as seeking the proper tone and rhythm; he was convinced that it was one of the important sources of poetic quality of the text. Hearing a word, he always sought a speaker, a live person who was uttering it. For this reason, his novelistic and dramatic worlds were resounding with a multitude of contrasting and complementary languages, dialects, voices of persons from all walks of life, different sexes and different professions or vocations. On the one hand, he wished to get close to the ideal language which would be transparent, the pure modern Chinese, while on the other he ventured into the realms of other arts, as if sensing that it is impossible to reach the linguistic whole. He was also a master of using the absence of language, the silence and quietude, particularly in theatre and in painting. He had some confidence in the contemplative journey among words, but he also guessed that the most important things are hidden behind or between the words, as suggested by his essay Literature and Metaphysics: About 'Soul Mountain'. Silence allowed him to keep a cool distance, to concentrate and carefully observe the fragments of the world passing him by, to collect his own and other persons' ephemeral sensations and transitory shapes of people and things. Gao was well aware that such trails of memory recorded in more or less credible stories finally lead to the mystery of things inexpressible and unspoken. 
The silence and quietude were related to emptiness which is a very important concept in Chinese aesthetics. It frequently appeared in Gao Xingjian's theatre and painting. In his essay The Means of Modern Theatre, he wrote about an empty stage without any decorations, lighting, sound effects, sophisticated costumes, with the attention focused on the actor, following the example of the Polish stage director and theatre reformer Jerzy Grotowski (who doubtlessly inspired him at a certain time). In mid 1980 os Gao wrote an article entitled What Kind of Theatre Do We Need? suggesting that modern Chinese theatre should reject the redundant burden of decorations and stage-props, turning to the tradition of the Beijing opera and various folk shows. It was one of his fundamental concepts of restoring the lost theatrical quality to the theatre. The empty stage allowed to return to convention seen as the essence of the theatre. An actor standing on such a stage was similar to a painter with a brush wet with ink in his hand suspended over the blank white expanse of paper. Using only the power of his talent, without any supports, he was able to create the most sophisticated worlds, events and characters on the naked stage. The empty stage, just as a blank piece of paper, gave to the artist and audience an unexpected freedom. It allowed their imagination to expand freely, not bound by the constraints of probability. Such a minimalist tendency, drove towards the reduced means of expression and even an asceticism of sorts was noticeable in Gao's paintings and plays. This in turn gave rise to his emotional reserve, intellectual distance and contributed to the remarkable elegance of his work which was always combined with the precise use of such means of expression. In his ink paintings and in plays which were built of carefully planned sequences of images, Gao Xingjian always cared for dynamic tension created by spatial arrangements of characters, stage-props and modest decorations. He used brightness and darkness, light and shade as if paining, and placed the actor on stage where a properly lit stage-prop could acquire symbolic meaning; this enabled Gao to create ambiguous images full of deep, hidden meaning and compliant with the principles of oneiric imagination which allowed for the coexistence of reality and imagination. In his ink paintings, he spread the ink on the paper creating blots of various intensity which overlapped, interfused and meshed together, creating the illusion of constant vibration and whirling. Such techniques disclosed the processual, dynamic nature of things and phenomena subject to incessant metamorphoses. All that surrounds us and all the creations of our imagination, all the past events and all feasible future events create a never-ending cycle of transformation: the rise, decline and regeneration. The recordings of such a stream of life resulted in a long novel, a short story or a play. It could create longer or shorter sequences or stories, or a series of recorded remarks or quick, film-like cuts or images. 
It always had an internal rhythm, and one could feel the pulse of the never-dwindling stream of energy in the fragile quality of the beauty, the elusive character of the sensations, ephemeral events, contrasted with the overwhelming burden of ugly, imperfect and depraved things.

What was the ultimate true face of the author? That of a curious writer, a leisurely traveller, and interesting story-teller? The deceiver or the deceived? A not-quite-trustworthy guide within the stream of unending transformations, among the plenitude of texts woven of words, sounds and images combined with sophisticated techniques? Or perhaps he was just asking questions? Perhaps he just led others to the edge but did not know the final answers...?

\section{| References}

Artaud, Antonin. The Theatre and Its Double. Trans. M.C. Richards. New York: Grove Press Inc., 1958.

Braun, Edward, ed. Meyerhold on Theatre. London: Methuen, 1969.

Butor, Michel. Répertoire. Études et conférences 1948-1959. Paris: Les Éditions de Minuit, 1960.

Butor, Michel. Réperoire. Études et conférences 1959-1963. Paris: Les Éditions de Minuit, 1964.

Gao, Xingjian. Dui yizhong xiandai xiju de zhuiqiu (In Search of Modern Theatre). Beijing: Zhongguo Xiju Chubanshe,1988.

Gao, Xingjian. "Dui yizhong xiandai xiju de zhuiqiu” (In Search of Modern Theatre). Dui yizhong xiandai xiju de zhuiqiu. Ed. Gao, Xingjian. Beijing: Zhongguo Xiju Chubanshe, 1988. Pp. 80-86.

Gao Xingjian. "Jinghua yetan” (Night Talks in Beijing). Dui yizhong xiandai xiju de zhuiqiu. Ed. Gao, Xingjian. Beijing: Zhongguo Xiju Chubanshe, 1988. pp.152-241.

Gao, Xingjjian. "Juzuofa yu zhongxing yanyuan” (Dramaturgical Method and the Neutral Actor). Meiyou zhuyi. Ed. Gao, Xingjian. Xianggang: Cosmos Books Ltd., 1996. pp. 253-266.

Gao, Xingjian. Meiyou zhuyi (Without -isms). Xianggang: Cosmos Books Ltd., 1996.

Gao, Xingjian. "Tan xiaoshuoguan yu xiaoshuo jiqiao" (On the Idea of Fiction and Writing Technique). Zhongshan6 (1982). Pp. 233-239.

Gao, Xingjian. Wenxue de liyou (The Case for Literature). Xianggang: Mingbao Chubanshe, 2001. 
Gao, Xingjian "Wenxue yu xuanxue: guanyu Lingshan” (Literature and Metaphysics: About Soul Mountain). Meiyou zhuyi. Ed. Gao, Xingjian. Xianggang: Cosmos Books Ltd., 1996. Pp. 167-182.

Gao, Xingjian. "Wo yu Bulaixite" (I and Brecht). Ed. by Gao, Xingjian. Dui yizhong xiandai xiju de zhuiqiu. Beijing: Zhongguo Xiju Chubanshe, 1988. Pp. 52-56.

Gao, Xingjian, "Xiandai hanyu yu wenxue dexiezuo" (Modern Chinese Language and Literary Composition). Wenxue de liyou. Ed. Gao, Xingjian. Xianggang: Mingbao Chubanshe, 2001. Pp. 2-26.

Gao, Xingjian. Xiandai xiaoshuo jiqiao chutan (Preliminaries to the Technique of Modern Narrative Prose). Guangzhou: Huacheng Chubanshe, 1982.

Gao, Xingjian. "Xiandai xiju shouduan" (The Means of ModernTtheatre). Dui yizhong xiandai xiju de zhuiqiu. Ed. Gao, Xingjian. Beijing: Zhongguo Xiju Chubanshe, 1988. Pp. 1-7.

Gao, Xingjian. "Xiqu buyao gaige yu yao gaige" (The Pros and Cons of the Reform of Traditional Chinese Music Drama). Ed. Gao, Xingjian. Dui yizhong xiandai xijude zhuiqiu. Beijing: Zhongguo Xiju Chubanshe, 1988. Pp. 71-76.

Gao, Xingjian. "Yao shenmeyang de xiju?" (What Kind of Theatre Do We Need?). Meiyou zhuyi. Ed. Gao, Xingjian. Xianggang: Cosmos Books Ltd., 1996. Pp. 62-70.

Gao, Xingjian. Bourgeois, Denis. Aux plus pres du réel. Dialogues sur l'écriture (1994-1997). Paris: Éditions de l'Aube, 1997.

Łabędzka, Izabella. Gao Xingjian's Idea of Theatre. From the Word to the Image. Leiden-Boston: Brill, 2008.

Willet, John, ed. Brecht on Theatre. The Development of an Aesthetics. London: Methuen, 2001.

\section{| Abstrakt}

IZABELLA ŁABĘDZKA

Dialog Gao Xingjian'a z tradycjami literackimi i wizualnymi

Niniejszy tekst poświęcony jest twórczości współczesnego chińskiego pisarza, dramaturga, malarza, inscenizatora i autora eksperymentalnych filmów artystycznych, Gao Xingjiana. Moim celem było pokazanie szerokich i nowatorskich poszukiwań pierwszego chińskiego Noblisty w zakresie różnorodnych sztuk i mediów w kontekście porównawczym Wschód - Zachód, jego umiejętności swobodnego prze- 
kraczania granic sztuk, wykorzystywania zasobów rodzimej kultury tradycyjnej oraz chińskiej filozofii taoistycznej z jej procesualnym rozumieniem rzeczywistości, a także estetyki pustki i artystycznego minimalizmu.

Słowa kluczowe: Gao Xingjian, intertekstualność, intermedialność, literatura chińska

\section{| Abstract}

\section{IZABELLA ŁABĘDZKA}

\section{Gao Xingjian's Dialogue with Literary and Visual Traditions}

The paper is devoted to the contemporary Chinese prose and drama writer, painter, stage director and author of experimental art films, Gao Xingjian. My aim is to present his innovative solutions in the field of different arts and media. I try to analyze his works in a broad context of Eastern and Western culture and to show the flexibility with which he crosses the narrow borders of arts, makes use of the rich heritage of his native traditional culture, Chinese Taoist philosophy with its processual understanding of reality. I also point at his interest in the aesthetics of emptiness and artistic minimalism.

Keywords: Gao Xingjian, intertextuality, intermediality, Chinese literature

\section{| Bio}

Izabella Łabędzka - profesor sinologii i tajwanologii. Ukończyła studia sinologiczne (Uniwersytet Warszawski) i teatrologiczne (PWsT w Warszawie). Doktoryzowała się w zakresie komparatystyki literackiej. Wielokrotna stypendystka na uniwersytetach chińskich, niemieckich, tajwańskich i w instytucjach naukowych Holandii. Specjalizuje się w zakresie porównawczych badań literatury, teatru i sztuki chińskiej oraz tajwańskiej. Publikowała swoje prace naukowe w Polsce i w Holandii (Brill).

Email: izalab@amu.edu.pl

ORCID: 0000-0002-8626-4802 
